\title{
TEACHERS' PERCEPTION OF THE USE OF ICT IN FOREIGN LANGUAGE TEACHING AT A HIGHER EDUCATION INSTITUTION
}

\author{
Maja Veljković Michos*, \\ Valentina Bošković Marković
}

Singidunum University,

Belgrade, Serbia

\begin{abstract}
:
The objective of this paper is to analyse and present the attitude of language teachers of a private higher education institution towards the use of ICT in the process of teaching foreign languages. Furthermore, the aim of the paper is to find out if teachers believe they have the skills and abilities necessary for the implementation of ICT tools. For this purpose, the authors have designed a questionnaire in order to examine if foreign language teachers feel motivated and prepared to implement new technologies as an integral part of their lectures. The results show a positive attitude of foreign language teachers regarding the incorporation of ICT tools in their classes, though they do not state that ICT tools are mandatory and/or essential in the language classroom. The research results also indicate that teachers use both traditional and ICT methods, which they find to be a perfect combination. These research results are very similar to the results of the previous research conducted by the same authors, but from students' perspective, regarding the usage of ICT tools in foreign language classroom.
\end{abstract}

Keywords:

Foreign language teaching, language teachers, ICT teaching methods.

\section{INTRODUCTION}

Foreign language courses have always been considered one of the fundamental aspects at Singidunum University in Serbia, due to the importance of foreign languages that may enable students to develop necessary linguistic competences and communication skills in order to obtain better employment and academic opportunities in different professional sectors or educational fields. Increasing access to new technologies ${ }^{1}$ in the modern media culture of the digital society has promoted the usage of technological tools in the classroom. Internet and technological devices take part in almost every class at each educational level.

Correspondence:

Maja Veljković Michos

e-mail:

mveljkovic@singidunum.ac.rs
$1 \quad$ In this paper, the term new technologies will be used to refer to a variety of concepts such as ICT (Information and Communication Technologies), digital technologies, modern technologies or emerging technologies, regarding technical innovations and communication technology supported with multi-functional devices that enable easier, faster and better communication and functioning of modern society. 
When it comes to foreign language teaching, new technologies also became an indispensable part of teaching practice due to multiple benefits of the usage of ICT tools and digital media for developing and practicing language skills [1]. On the other hand, the integration of ICT in the educational process should rely on teachers' pedagogically grounded and responsible use with clear educational goals, the real impact on teaching practice, the relevance for the objective needs and interests of students, and it is important to avoid their use as a fashionable practice [2]. In that context, the opinion and perceptions of both protagonists in the learning-teaching process (students and teachers) regarding the impact of the usage of new technologies in a foreign language classroom is a fundamental aspect to know and analyse for further improvement of a language teaching process. The methodology used in this paper was based on the analysis of literature related to teacher perception, the impact of ICT and its level of use. The information was collected from university language teachers of foreign languages, through the application of a questionnaire that enabled the authors to identify the opinion of teachers. It is also relevant to determine which tools bring benefit to the language teaching process in the classroom and what kind of teaching dynamics can be applied with a positive impact on learning in a physical classroom, but in the virtual classroom ${ }^{2}$ too, in an online teaching environment. For this paper, the authors have designed a questionnaire as a research instrument. The questionnaire consists of a series of questions whose aim is to gather information from teachers of foreign languages at university level, in order to know their opinions based on teaching experiences regarding the use of new technology in teaching practice, and to identify the relevance for the needs and interests of students. The questionnaire was shared with eighteen teachers, who are all employed at Singidunum University. This research follows the study which was conducted last year regarding students' perception of the ICT oriented work in a foreign language classroom vs traditional methodology of teaching/learning at the same university context [3]. In other words, the same aspects are covered, but a different sample is used.

2 The main difference between the physical and virtual classroom is based on students' and teachers' possibility to share the same physical space, to see and hear each other, on the fact that the whiteboard and learning materials are in real time, as well as on the difference regarding collaborative work in direct contact. In a virtual classroom, a student can see, hear and interact with their teacher and other students in real time via the video-audio stream.

\section{STUDENTS' AND TEACHERS' PERCEPTIONS ON ICT IN A LANGUAGE CLASSROOM}

The implementation of ICT has a significant and dynamic increase, especially when it comes to higher education [4] [5]. A teacher as a subjective critic of ICT can highlight the deficiencies, but also recognize ICT potential in the teaching and learning process. According to the definitions of the concept of perception, resumed in [6], perception, as the inner sensation that results from a material impression made on the senses, has the function to make abstractions through the qualities that define the essentials of external reality. Following these concepts, studies on the attitudes of teachers towards the new technologies have tended to distinguish different groups based on attitudes [6]:

- ICT is essential in the teaching-learning process.

- ICT is important for certain activities of the teaching-learning process.

- ICT is not a useful tool within the teaching-learning process.

Different attitudes and perceptions of language teachers towards ICT depend on variables of a teacher such as: gender, age, academic level, ICT skills, linguistic and pedagogical competences, etc. Other variables which are relevant refer to the environment, and they can include: resources, attitude of management, contents, syllabus, working environment, technological infrastructure, time management, etc. Finally, a teacher's perception of ICT is shown with the level or grade of its usage, in accordance with the teacher's opinion, as well as in compliance with the influence that ICT can have in the language classroom at a higher education institution. Although some studies show that private university teachers have more favorable perception of the use of ICT in teaching practice than teachers of the public universities [5], the difference in perception can be caused by various aspects in all institutions, such as lack of training programmes in ICT, or limitations in investment in technological infrastructure for teaching and research, as well as factors such as computers, Internet connections, whiteboards in classrooms, intranets, good ICT coordination, and fundamental didactical training in technology [5]. In order to achieve effective learning, the potential of ICT is a significant tool that can improve students' learning strategies [7]. When it comes to effective teaching, necessary skills of the professionals of the digital society and professional teachers' 
competences include the use of new technologies and effective communication with students, along with team work, evaluation and educational research, in order to achieve competency to select relevant, updated teaching material and implementation of main ICT elements in teaching practice: devices, programs/applications, and web content [8]. This paper, which is focused on the attitudes of foreign language teachers, was conducted as an additional research to the previous study based on students' perception of the impact and benefits of implementation of new technologies and ICT tools in a foreign language classroom, teaching activities, practice and assessment. According to students' answers ${ }^{3}$, ICT tools do not have an essential impact on their learning, but they represent an optional and additional aspect that can help language learning, whereas traditional materials such as textbooks and workbooks in paper format are still considered to be a basic useful tool that helps them improve learning a foreign language, regardless of which language that is [3]. According to another research about students' perception of ICT, the students with higher academic results recognise a greater potential of ICT to support their learning strategies, although all students show positive valuation of ICT to improve and facilitate the preparation of work, organise their academic activity, review tasks, work with classmates, find resources and fulfill their academic tasks [7]. In the same way, the research we referred to previously [3] shows that almost $50 \%$ of the students who participated in the research claim that they prefer to practice foreign language with a textbook, which is a form of a traditional teaching method. When asked if students can imagine their language class without the use of ICT, $51.6 \%$ of answers were positive, which implied the conclusion that, although students perceive ICT as a significant tool for their learning (91.6\%), they highly value the teacher's role with presentations, lectures and explanations in the language classroom. The language teachers at the same institution have confirmed that they receive the same opinion from their students in classrooms, when they discuss these issues in language classes. Students do not have expectations about the teaching strategy and tools or media their language teachers might use. However, what they claim and point out to be important is the learning objective which needs to be clear and the usage of class material with online tools in order to help students to develop their language skills.

3 The research conducted in 2019 implied a quantitative analysis among 119 male and female students who study at Singidunum University in Belgrade, Serbia (Faculty of Business, Faculty of Tourism and Hospitality Management, and Faculty of Technical Sciences).
Accordingly, the role of the language teacher is indispensable for effective learning, as $64.7 \%$ of students answered that they agree, and $27 \%$ of students strongly agree that a language teacher's lectures, presentations and explanations are more effective for learning than the use of ICT tools.

\section{RESEARCH METHODOLOGY AND RESULTS}

As stated previously, the research conducted for the purpose of this paper is similar to the previous research by the same authors, presented in 2019 [3], whose aim was to analyse students' perspective. As this time the focus is on foreign language teachers and their opinion and experience, this quantitative analysis aimed to discover and analyse whether teachers found teaching in ICT- oriented classroom easier or more difficult, and more or less useful than teaching in the traditional classroom.

The instrument used for this study was an online, anonymous questionnaire which foreign language teachers (English, Spanish, German, Italian, Russian, French) were asked to fill in. As the sample for the previous study included only the students from Singidunum University, this study also included only teachers from Singidunum University (18 foreign language teachers). The 14 questions given to teachers were mostly multiple choice questions and they could choose only one answer per question, whereas some of the questions were open-ended. Even though this sample might be considered small, the point of the study was to discover the perspective of teachers at a higher education institution who certainly use ICT in the classroom, which is why teachers at Singidunum University have been chosen as the only examinees. The biggest percentage of the examinees, $44.4 \%$ ( 8 teachers) teach the English language, whereas $16.7 \%$ of them (3 teachers) teach the Spanish language, also $16.7 \%$ of them (3 teachers) teach the German language; $11.1 \%$ (2 teachers) teach the Russian language, $5.6 \%$ (1 teacher) of them teach the Italian language, and 5.6\% (1 teacher) teach the French language. More than $50 \%$ of our examinees have been teaching for more than ten years, whereas the rest of them have at least five years' experience. All of them have Internet connection and a computer in their classroom and $61.1 \%$ of them often use it (once a week), whereas $38.9 \%$ of them always use it (in all classes).

When asked which online or digital tools they prefer (e.g. platforms, online activities, websites, devices), the biggest percentage of teachers $(22.2 \%)$ chose online 
interactive activities such as educational websites and educational application Quizlet ${ }^{4}$, whereas YouTube, as a significant online resource for language learning and teaching with authentic language content, and Kahoot ${ }^{5}$, a recognized learning tool for gamified language teaching and learning [9], were only chosen by $5.6 \%$ each. Other mentioned applications were Madtakes ${ }^{6}$ and Quizizz?.

When asked whether they feel comfortable when using digital tools in the classroom, $83.3 \%$ of the examinees ( 15 teachers) said yes, and $55.6 \%$ of them confirmed that they are skilled enough for using ICT tools. However, when asked whether they thought that the usage of ICT should be mandatory in a language classroom, more than half of the examinees (55.6\%) said no. Also, $50 \%$ of teachers claimed that their language class is often traditional (e.g. the usage of a textbook, workbook, or a whiteboard), even though $88.9 \%$ of them find it easier to teach a language with ICT tools. Moreover, only one teacher thinks that their lectures and explanations are more effective than the use of ICT tools, and $66.7 \%$ of them think that their students prefer learning a foreign language with a textbook and a workbook to learning with a computer and Internet. The same percentage of teachers claim that they can imagine their language classroom without the usage of ICT tools. In the conclusion, the same percentage of teachers (66.7\%) do not think that the usage of ICT in teaching has an influence on the students' attendance in the classroom. In the following tables, some of the answers which illustrate the perception of foreign language teachers at Singidunum University regarding the application of new technology tools in their teaching practice are presented.

\begin{tabular}{|c|c|c|}
\hline Question & $\begin{array}{r}\text { Do you th } \\
\text { sh }\end{array}$ & $\begin{array}{l}\text { ef ICT tools } \\
\text { ry in a } \\
\text { om? }\end{array}$ \\
\hline \multirow{2}{*}{ Answer } & $38.9 \%$ & $55.6 \%$ \\
\hline & Yes & No \\
\hline
\end{tabular}

Table I. Teachers' opinion on the usage of ICT in the language classroom.

\begin{tabular}{ccc}
\hline Question & \multicolumn{2}{c}{$\begin{array}{c}\text { Do you feel comfortable when using digital } \\
\text { tools in the classroom? }\end{array}$} \\
\cline { 2 - 3 } Answer & $83.3 \%$ & $16.7 \%$ \\
\cline { 2 - 3 } & Yes & No \\
\hline
\end{tabular}

Table II. Teachers' answer to the question whether they feel comfortable when using ICT tools in classroom.

\begin{tabular}{lcc}
\hline Question & \multicolumn{2}{c}{$\begin{array}{c}\text { Are your lectures and explanations more } \\
\text { effective than the use of ICT tools? }\end{array}$} \\
\cline { 2 - 3 } Answer & $94.4 \%$ & $5,6 \%$ \\
\cline { 2 - 3 } & Yes & No \\
\hline
\end{tabular}

Table III. Teachers' opinion on the effectiveness of their teaching suported with ICT tools.

\begin{tabular}{|c|c|c|c|}
\hline Question & $\begin{array}{l}\text { Do yo } \\
\text { contri }\end{array}$ & $\begin{array}{l}\text { hink tl } \\
\text { utes to }\end{array}$ & $\begin{array}{l}\text { using ICT in the classroom } \\
\text { tter language acquisition of } \\
\text { students? }\end{array}$ \\
\hline \multirow[b]{2}{*}{ Answer } & $77,8 \%$ & $5.6 \%$ & $5.6 \%$ \\
\hline & Yes & No & $\begin{array}{l}\text { Sometimes, like additional } \\
\text { tool }\end{array}$ \\
\hline
\end{tabular}

Table IV. Teachers' opinion on whether the ICT affects the learning of students.

\begin{tabular}{cccc}
\hline Question & \multicolumn{3}{c}{ How often is your language class traditional? } \\
\cline { 2 - 4 } & $33.3 \%$ & $50 \%$ & $16.7 \%$ \\
\cline { 2 - 4 } Answer & Always & Often & Rarely \\
\hline
\end{tabular}

Table V. Teachers' answer to the question about traditional methodology in their classroom.

\begin{tabular}{cccc}
\hline Question & \multicolumn{3}{c}{$\begin{array}{r}\text { Do you think that your students expect you to } \\
\text { use ICT tools in the classroom? }\end{array}$} \\
\cline { 2 - 4 } Answer & $44,4 \%$ & $44,4 \%$ & $5.6 \%$ \\
\cline { 2 - 4 } & Yes & No & Not sure \\
\hline
\end{tabular}

Table VI. Teachers' opinion on students' expectations regarding their usage of ICT tools in the classroom.

\begin{tabular}{|c|c|c|c|c|}
\hline \multirow[b]{2}{*}{ Question } & \multicolumn{4}{|c|}{ Which online/ digital tools do you prefer to use? } \\
\hline & $11,1 \%$ & $22.2 \%$ & $5,6 \%$ & $5.6 \%$ \\
\hline Answer & $\begin{array}{c}\text { Online } \\
\text { interactive } \\
\text { activities }\end{array}$ & $\begin{array}{l}\text { Educational } \\
\text { platforms } \\
\text { and appli- } \\
\text { cations }\end{array}$ & $\begin{array}{l}\text { You- } \\
\text { Tube }\end{array}$ & Kahoot \\
\hline
\end{tabular}

Table VII. Online tools that teachers mostly use in their language classroom.

\begin{tabular}{|c|c|c|c|}
\hline \multirow[t]{2}{*}{ Question } & \multicolumn{3}{|c|}{$\begin{array}{c}\text { Can you imagine your language class withou } \\
\text { the use of ICT? }\end{array}$} \\
\hline & $66,7 \%$ & $33,3 \%$ & $0 \%$ \\
\hline Answer & Yes & No & Not sure \\
\hline
\end{tabular}

Table VIII. Teachers' opinion on the ICT-free classroom. 


\section{CONCLUSION}

Students and language teachers in the university context where the research was conducted share the general opinion regarding the positive impact of the new technology in language classroom as a tool that can help to acquire language contents and improve effective teaching. The teachers who were examined believe that the implementation of ICT is an expected approach in language teaching in academic classroom. However, according to the study referring to students' opinion which has been published in the previous paper by the same authors, new technology is not an essential, but an additional aspect in the classroom. When it comes to the traditional materials in paper form such as textbooks and workbooks, students and teachers and they share the same opinion. Although some teachers believe that students expect the usage of technological devices, online platforms, applications and other ICT tools during lectures in the class that will replace the traditional role of the textbook or intervention of the human factor, such as teacher and student verbal interaction, students support any methodology (which is either supported by ICT or not) that may help the improvement of their language and communication skills and which includes language effective practice in every class. On the other hand, teachers' pedagogical competences regarding foreign language teaching with appropriate ICT skills may enhance a more functional and effective language learning in university classroom. The needs and interests of students do not necessarily have to comply with teachers' perceptions. For this reason, teachers may use research instruments such as questionnaires to know both students' and teachers' expectations better, to be aware of their needs and learning/teaching styles, and perception regarding the teaching and learning process, in order to improve their language skills and make foreign language learning more effective. As far as teachers are concerned, the usage of ICT tools is becoming an essential part of a language classroom, though traditional teaching methods are still not obsolete. According to the opinion of teachers who participated in the questionnaire for this research, although they state that they feel comfortable using ICT tools in their classroom $(83,3 \%)$ and perceive new technology as a tool that contributes to better language acquisition of students $(77,8 \%)$, teachers also often (50\%) or always (33,3\%) apply traditional methodology in the teaching practice, which shows that they consider benefits of innovative methodologies assisted with new technology, but do not discard the proven traditional formulas for effective teaching and learning.

It is also important to mention that this study was conducted before the outbreak of COVID-19 pandemic, and that the authors believe that teachers might give different answers to some questions from the questionnaire (e.g. 'How often do you use Internet and ICT in your classroom', 'Do you think you are skilled enough for using ICT tools', etc.) now that they have been required to implement ICT tools as the only language teaching tool, due to virtual classes all over the world. Furthermore, the authors believe that several other studies should be introduced in order to fully understand the attitude of both teachers and students towards the usage of ICT tools in the classroom, especially when it comes to comparing the attitudes of teachers and students and comparing these attitudes before COVID-19 and during COVID-19 pandemic. With that in mind, the authors of this paper are currently working on the comparative analysis of the attitudes of students and teachers towards the usage of ICT tools in the language classroom, and the results of that study are to be published soon.

\section{REFERENCES}

[1] Gilakjani, Abbas Pourhosein. "A review of the literature on the integration of technology into the learning and teaching of English language skills." International Journal of English Linguistics 7.5, 2017, pp. 95-106.

[2] Velea, S. "ICT in education: responsible use or a fashionable practice. The impact of eTwinning action on the education process". In ICVL. Proceedings of the 6th International Conference on Virtual Learning. Bucharest: University of Bucharest Publishing House, 2011.

[3]. Veljković Michos, M.; Nasradin, K.; Bošković Marković, V.; "Traditional Language Teaching Versus ICT Oriented Classroom". In Sinteza 2019 International Scientific Conference on Information Technology and Data Related Research, Apr, 2019, pp. 627-632.

[4] Sigalés, C. Formación universitaria y TIC: nuevos usos y nuevos roles. Revista de Universidad y Sociedad del Conocimiento (RUSC), 2004, vol. 1, № 1.

[5] Marqués Graells, P. Impacto De Las Tic En La Educación: Funciones Y Limitaciones. 3C TIC. Cuadernos De Desarrollo Aplicados a Las TIC, Vol. 2, n. ${ }^{\circ}$, Jan. 2013.

[6] Riascos-Erazo, S. C., Ávila-Fajardo, G. P., \& Quintero-Calvache, D. M. Information Technology in the Classroom: The views of university professors. Educación y Educadores, 12(3), 2009, pp. 133-157. 
[7] Muñoz-Repiso, Ana García-Valcárcel, and Francisco Javier Tejedor Tejedor. "Percepción de los estudiantes sobre el valor de las TIC en sus estrategias de aprendizaje y su relación con el rendimiento." Educación xx1 20.2, 2017, pp. 137-159.

[8] M. A. Zabalza, Competencias docentes del profesorado universitario. Calidad y desarrollo profesional, Madrid, Narcea, 2003, pp. 71-168.

[9] Veljković Michos, M. "Gamification in Foreign Language Teaching: Do You Kahoot?". In Sinteza 2017-International Scientific Conference on Information Technology and Data Related Research. Singidunum University, 2017, pp. 511-516. 